\title{
EVALUASI SEKOLAH LAPANG SISTEM TANAM PADI JAJAR LEGOWO SUPER DENGAN METODE TYLER
}

\author{
Evaluation of Jajar Legowo Super System Field School using Tyler Method \\ Khaerunnisa1; Reni Suryanti ${ }^{2}$ \\ ${ }^{1}$ SMK Dharma Shalihat Darul Makmur Nagan Raya \\ ${ }^{2}$ Politeknik Pembangunan Pertanian Bogor \\ *Korespondensi penulis, Email: Khairunnisa_piliang@apps.ipb.ac.id
}

Diterima: 5 September 2020

Disetujui terbit: 28 November 2020

\begin{abstract}
Field school is one of the extension approaches to disseminate technology in rice cultivation. Evaluation of field schools can be done by using the Tyler method. The objectives of this study were (1) to analyze the understanding of farmers (knowledge, attitudes and skills) in implementing the cultivation of jajar legowo super systems of rice; (2) identify the achievement of extension in field school. The results showed that the farmers' knowledge, attitudes and skills were at moderate to high levels. Evaluation using the Tyler model shows that the objectives of the outreach activity through field schools have been achieved.
\end{abstract}

Keywords: jarwo super, field school, evaluation of extension

\section{ABSTRAK}

Sekolah lapang merupakan salah satu pendekatan penyuluhan untuk mensosialiasikan teknologi pertanian. Evaluasi keberhasilan penyuluhan dalam sekolah lapang jajar legowo super dapat dilakukan dengan evaluasi penggunakan metode Tyler. Tujuan penelitian ini adalah (1) menganalisis pemahaman petani (aspek pengetahuan, sikap dan keterampilan) dalam melaksanakan budidaya tanaman padi sistem jajar legowo super; (2) mengidentifikasi pencapaian kegiatan penyuluhan dalam kegiatan sekolah lapang. Hasil penelitian menunjukkan pengetahuan, sikap dan keterampilan petani terkait teknologi jarwo super berada pada tingkat sedang sampai dengan tinggi. Evaluasi dengan model Tyler menunjukkan bahwa tujuan kegiatan penyuluhan melalui sekolah lapang jajar legowo super telah tercapai.

Kata kunci: jajar legowo super, sekolah lapang, evaluasi penyuluhan.

\section{PENDAHULUAN}

Upaya meningkatkan produksi

padi dapat dilakukan melalui penerapan teknogi yang tepat. Salah satu teknologi yang ditawarkan oleh Kementerian Pertanian kepada petani adalah sistem tanam jajar legowo yang kemudian dimodifikasi menjadi sistem tanam jajar legowo super. Sistem tanam jajar legowo merupakan bagian dari
Pengelolaan Tanaman dan Sumberdaya Terpadu (PTT). PTT adalah pendekatan dalam peningkatan produksi melalui pengelolaan tanaman, tanah, air, hara dan organisme pengganggu tumbuhan (OPT) secara menyeluruh dan berkelanjutan. Dalam penerapannya, PTT bersifat partisipatif, dinamis, spesifik lokasi, terpadu dan sinergis antar komponen teknologi yang diterapkan 
Sistem tanam jajar legowo diyakini sebagai sistem penanaman yang efektif untuk meningkatkan produksi padi. Penanaman dengan sistem jajar legowo yang menyediakan baris kosong sebagai ruang tumbuh yang lebih longgar, memberikan sirkulasi udara dan pemanfaatan sinar matahari lebih baik untuk pertanaman. Selain itu upaya penanggulangan gulma dan pemupukan dapat dilakukan dengan lebih mudah.

Penanaman dengan sistem jajar legowo berpeluang menghasilkan gabah yang lebih tinggi karena lebih banyaknya fotosintesis yang terjadi. Hal ini disebabkan lebih efektifnya tanaman menangkap radiasi surya dan mudahnya difusi gas CO untuk fotosintesis. Lin et al, (2009), menyatakan jarak tanam yang lebar dapat memperbaiki total penangkapan cahaya oleh tanaman dan dapat meningkatkan hasil biji. Lebih lebarnya jarak antar barisan dapat memperbaiki total radiasi cahaya yang ditangkap oleh tanaman dan dapat meningkatkan hasil. Sistem tanam jajar legowo memiliki jumlah rumpun per satuan luas lebih banyak dibandingkan cara tanam tegel yang setara. Ikhwani et al., 2013) menyatakan, tanam tegel 25 $\mathrm{cm} \times 25 \mathrm{~cm}$ memiliki populasi 160.000 rumpun per ha, sedangkan legowo $2: 1$ yang setara dengan $25-50 \mathrm{~cm} \times 12,5 \mathrm{~cm}$ memiliki populasi 213.333 rumpun. Penerapan sistem tanam jajar legowo yang sesuai dengan kondisi lingkungan setempat diharapkan akan meningkatkan produktivitas tanaman padi dan keuntungan bagi petani.

Teknologi Padi Jajar Legowo Super (Jarwo Super) merupakan pengembangan teknologi jarwo. Jarwo super merupakan teknologi penenaman padi berbasis jajar legowo dan menggabungkan berbagai teknologi lainnya untuk menghasilkan produksi dan produktivitas optimum. Dalam publikasi Petunjuk Teknis Balitbangtan (2016), definisi Teknologi Padi Jarwo Super adalah teknologi budidaya terpadu padi sawah irigasi berbasis tanam jajar legowo 2:1. Komponen teknologi jajarlegowo super terdiri dari : 1) varietas unggul baru (VUB) potensi hasil tinggi, 2) biodekomposer (M-Dec), 3) pupuk hayati sebagai seed treatment (Agrimeth); 3) pemupukan berimbang berdasarkan Perangkat Uji Tanah Sawah (PUTS), 4) pengendalian OPT menggunakan pestisida nabati dan pestisidan anorganik serta 5) alat dan mesin pertanian, khususnya untuk tanam (jarwo transplanter) dan panen (combineharvester).

Pemahaman petani terhadap teknologi tanam jajar legowo super padi menjadi penting agar manfaat yang akan diperoleh dari penerapannya akan lebih optimal. Pendekatan penyuluhan yang efektif untuk mensosialisaikan teknologi 
ini adalah dengan metode penyuluhan sekolah lapang. Melalui sekolah lapangan petani belajar secara langsung dan melihat serta melakukan sendiri proses penerapan suatu inovasi. Pada sekolah lapang, petani berpartisipasi untuk belajar menerapkan suatu teknologi. Pendekatan penyulahan dengan sekolah lapang merupakan metode yang sesuai bagi pembelajaran orang dewasa yang bersifat partisipatif dan sesuai kebutuhan.

Sebagai sebuah kegiatan penyuluhan, sekolah lapang sistem jajar legowo super merupakan program kegiatan pembangunan di pedesaan yang keefektifan pelaksnaannya perlu dievaluasi. Evaluasi program merupakan upaya mencari informasi tentang pelaksanaan program yang telah berjalan dan memberikan rekomendasi bagi program terkait dimasa yang akan datang. Terdapat banyak metode yang dapat digunakan dalam melakukan evaluasi program kegiatan. Metode yang dikembangkan Tyler yang dikenal juga dengan metode evaluasi berorientasi tujuan merupakan salah satu metode evaluasi yang dapat digunakan (Arikunto dan Jabar, 2009). Metode ini dikembangkan oleh Ralp Tyler pada tahun 1940-50 pada bidang pendidikan dan kemudian diaplikasikan banyak kalangan pada program di bidang lainnya. Tyler merumuskan evaluasi hasil belajar dari tujuan pembelajaran berdasarkan taksonomi tujuan pembelajaran yang dikembangkan oleh Bloom dan Krathwohl (Putra, 2012)

Keunggulan model ini yaitu cenderung mudah dipahami, mudah diikuti, mudah diterapkan dan juga mudah disetujui untuk diteliti menjadikan metode Tyler telah banyak di aplikan di berbagai bidang. Pendekatan ini telah menstimulasi pengembangan teknik, prosedur pengukuran dan instrumen. Penekanan metode evaluasi ini adalah pada pengukuran pencapaian tujuan program melalui pengembangan instrumen yang tepat. Dengan pendekatan ini evaluator bisa melihat lebih jelas hasil pencapaian dari suatu program sehingga bisa menilai dan menimbang prgram tersebut dengan tepat.

Berdasarkan uraian diatas maka tujuan penelitian ini adalah menganalisis pemahaman petani (aspek pengetahuan, sikap dan keterampilan) dalam melaksanakan budidaya tanaman padi sistem jajar legowo super; (2) Mengetahui pencapaian kegiatan penyuluhan SL Jarwo Super.

\section{METODE PENELITIAN}

Lokasi dan Waktu

Penelitian dilakukan di Kelurahan Situ Gede Kota Bogor, yaitu di Kelompok 
Wanita Tani Delima. Penelitian dilaksanakan pada bulan Mei 2017.

Responden

Responden penelitian adalah 20 orang petani anggota KWT Delima yang telah mengikuti SL Jarwo Super pada tahun 2016. Sumber informasi lain untuk menjawab tujuan penelitian adalah ketua dan pengurus KWT Delima, penyuluh pertanian dan tokoh masyarakat.

Data dan Sumber Data

Data yang dikumpulkan guna melakukan penelitian terdiri atas data primer dan data sekunder. Data primer terkait dengan pelaksanaan SL jarwo super yakni tentang proses pembelajaran dalam SL, peningkatan produksi padi, pengalaman belajar yang dirasakan oleh petani, serta pengorganisasian proses belajar dalam SL. Sedangkan data sekunder berkaitan dengan potensi wilayah, kebijakan pemerintah terkait dengan program SL jarwo super serta data lain yang mendukung terjawabnya tujuan penelitian.

Data primer diperoleh dari responden petani, penyuluh, tokoh masyarakat dan aparat dinas pertanian. Data sekunder diperoleh dari laporan dan dokumen serta litertur terkait.

Instrumen dan Teknik Pengumpulan Data

Instrumen yang digunakan adalah kuisioner dan panduan wawancara.
Instrumen digunakan untuk menggali informasi dari responden petani, berisi pertanyaan tertutup terkait dengan program SL Jarwo Super. Sedangkan panduan wawancara merupakan panduan yang berisi pertanyaan secara umum dan dikembangkan dalam wawancara terhadap informan kunci.

Pengolahan dan Analisis Data

Pengolahan data dilakukan secara deskriptif dan disesuaikan dengan tujuan penelitian. Data yang diperoleh diolah dan dianalisis dengan mengkategorikan, menghitung jawaban dan mempresentasekan berdasarkan golongan jawaban.

Data terkait dengan pengetahuan petani tentang sistem jajar legowo di kategorikan atas nilai 1 untuk jawaban yang benar dan nilai nol untuk jawaban yang tidak benar. Dari keseluruhan jawaban responden dapat dipresentasikan jumlah jawaban benar dan salah, sehingga dapat dihitung tingkat pengetahuan petani tentang Jarwo Super.

Data sikap petani tentang SL jarwo super diberi skort mengacu pada skala lingker dengan empat tingkatan skoring. Jawaban setiap pertanyaan terdiri dari pilihan data berskala ordinal 1 sampai dengan 4, yang merepresentasikan nilai dengan simbol kuantitatif, dan merupakan gradasi dari sangat tidak setuju sampai dengan sangat setuju. 
Penentuan posisi tanggapan responden dengan menggunakan nilai skor setiap variabel, bobot alternative jawaban yang terbentuk dari teknik skala peringkat terdiri dari kisaran antara 1 hingga 4 yang digambarkan posisi yang negatif ke posisi yang positif. Rentang skala dihitung dengan rumus sebagai berikut:

$R s=\frac{R(\text { bobot })}{M}$

Dimana :

$$
\begin{array}{ll}
\mathrm{Rs} & =\text { Rentang skala } \\
\mathrm{R}(\text { bobot })= & \text { bobot terbesar dikurangi } \\
& \text { bobot terkecil } \\
\mathrm{M} & =\text { banyaknya katagori bobot }
\end{array}
$$

Rentang skala likert yang digunakan dalam penelitian ini adalah 1 hingga 4, rentang skala dikategorikan atas tiga tingkatan yakni tinggi, sedang dan rendah. Rentang skala dihitung dengan mengurangi nilai maksimal (nilai maksimal dikali jumlah item) dengan nilai minimal (nilai minimal dikali jumlah item) dibagi tiga sehingga rentang skala penilaian yang di dapat adalah :

$R s=(($ jumlah item $\times 4)-\quad$ (jumlah item $\mathrm{x} 1)) / 3$

Setelah dilakukan pengolahan data dengan tabulasi dan statistik deskriptif langkah selanjutnya adalah menginterpretasikan informasi yang diperoleh. Interpretasi disesuikan dengan tujuan penelitian dan didukung dengan teori dan konsep yang terkait SL Jarwo Super.

\section{HASIL DAN PEMBAHASAN}

\section{Karakteristik Petani}

Hasil analisis data karakteristik petani responden ditunjukan pada Tabel 2. Karakteristik wanita tani meliputi umur, tingkat pendidikan, pengalaman usahatani, dinyatakan dalam satuan tahun sedangkan frekuensi mengikuti SL Jarwo dinyatakan dalam satuan kali dan luas lahan dalam satuan hektar. Selanjutnya diambil nilai rata-rata dari masing-masing karakteristik untuk mengetahui pada tingkatan mana masing-masing karakteristik itu berada.

Umur responden berkisar antara 26-62 tahun dan rataan umur 44,8 tahun yang dikategorikan sebagai petani dewasa. Ini berarti sebagian besar umur petani termasuk usia produktif. Umur mempengaruhi seseorang dalam merespon sesuatu yang baru walaupun belum banyak mempunyai pengalaman dan lebih mudah serta cepat dalam menerima inovasi. Hal tersebut sejalan dengan pernyataan Lionberger) dalam Mardikanto (2009) yang menyatakan semakin tua (diatas 50 tahun) biasanya semakin lamban mengadopsi inovasi dan cenderung banyak melaksanakan kegiatan-kegiatan yang sudah biasa diterapkan oleh warga masyarakat setempat. 
Tabel 2. Distribusi Karakteristik Wanita Tani

\begin{tabular}{|c|c|c|c|c|}
\hline No. & Karakteristik & Minimal & Maximal & Rataan \\
\hline 1. & Umur (tahun) & 26 & 62 & 44,8 \\
\hline 2. & Tingkat Pendidikan (tahun) & 6 & 12 & 7,7 \\
\hline 3. & $\begin{array}{l}\text { Pengalaman Usahatani } \\
\text { (tahun) }\end{array}$ & 2 & 50 & 12,1 \\
\hline 4. & Frekuensi mengikuti SL Jarwo & 1 & 4 & 3,8 \\
\hline 5. & Luas Lahan (ha) & 0,02 & 1,3 & 0,3 \\
\hline
\end{tabular}

Tingkat pendidikan formal merupakan lama pendidikan yang ditempuh responden pada bangku sekolah. Tingkat pendidikan responden pada penelitian ini sebagian rata-rata 7,7 tahun atau sama dengan berpendidikan SMP yang berarti berada pada kategori sedang. Mengacu pada pendapat Roger dan Shoemaker (1981) suatu tantangan bagi penyuluhan pertanian dalam mengembangkan pembelajaran yang menarik bagi petani dengan tingkat pendidikan yang relatif masih rendah sehingga dapat menerapkan adopsi dengan lebih cepat.

Pengalaman berusahatani responden termasuk kategori rendah. Pengalaman berusahatani dalam penelitian ini merupakan jumlah tahun lamanya responden bekerja sebagai petani padi sampai saat penelitian ini dilakukan. Pengalaman berusahatani cenderung memengaruhi keputusan yang diambil petani pada kegiatan usahatani berikutnya. Seluruh anggota kelompok wanita tani masih sangat bergantung pada keberadaan penyuluh dalam melakukan usahatani sehingga dapat dikatakan responden masih tergolong petani pemula.

Frekuensi petani responden dalam mengikuti SL Jarwo yaitu sebanyak 1-4 kali, dengan rata-rata pertemuan 3,8 kali. Pertemuan tersebut belum sepenuhnya mampu mendiseminasikan inovasi secara tepa. Hal ini dapat dibuktikan dari hasil wawancara bahwa petani belum mengetahui Teknologi Jarwo Super secara lengkap. Petani responden masih membutuhkan bantuan petani lain dan penyuluh dalam melaksanakan kegiatan usahatani mereka.

Luas lahan petani responden dalam penelitian ini yaitu keseluruhan lahan yang digunakan petani dalam melaksanakan budidaya padi, baik itu milik sendiri, sewa dan bagi hasil. Berdasarkan hasil akumulasi wawancara petani responden memiliki luas lahan garapan sebesar 0,02-1,3 $\mathrm{Ha}$, dengan rata-rata 0,3 Ha. Luasan lahan tersebut 
tergolong pada kepemilikan lahan sempit, sehingga sulit bagi petani untuk meningkatkan produktifitas usahatani mereka. Luas lahan tersebut sangat berpengaruh pada motivasi petani dalam mengadopsi inovasi.

\section{Proses Pelaksanaan SL Jarwo Super} Informasi tentang proses pelaksanaan SL dilakukan dengan serangkaian pertanyaan dalam kuisioner. Pertanyaan tentang proses berkaitan dengan materi, narasumber, metode penyuluhan dan partisipasi peserta dalam kegiatan SL. Hasil analisis menunjukkan bahwa secara keseluruhan petani menilai proses yang berjalan pada SL ini berada pada tingkat baik/tinggi (72,22\%). Hal ini menunjukkan bahwa petani puas dengan kegiatan SL yang dilaksanakan.

Analisis perbutir pernyataan tentang proses SL menunjukkan bahwa petani menilai sedang dan tinggi untuk setiap butir proses. Terkait dengan kesesuaian materi SL dengan kebutuhan petani, dinilai petani cukup sesuai. Sedangkan untuk butir pertanyaan tentang pemateri, metode penyuluhan, praktek dan pengamatan partisipatif direspon tinggi (sangat baik) oleh petani. Hal ini mengindikasikan bahwa petani merasakan bahwa proses yang berjalan pada SL ini telah berjalan baik dengan materi dan pendekatan penyuluhan yang menyenangkan, sesuai dengan prinsip pembelajaram orang dewasa dan partisipatif.

Sekolah lapang merupakan proses pendidikan non formal yang diperuntukan bagi petani sebagai orang dewasa dengan mengedepankan prinsip partisipatif. SL dihaparkan dapat meningkatkan pengetahuan, sikap dan keterampilan petani melalui peroses menyusun rencana usaha, melakukan identifikasi masalah, mengambil keputusan dan menerapkan teknologi. mengatasi masalah, mengambil keputusan, dan menerapkan teknologi yang sesuai dengan sumber daya setempat. Melalui sekolah lapang petani sama sama be;ajar dan berbagi pengfalaman. Kegiatan penyuluhan dalam sekolah lapang ini merupakan kegiatan penyuluhan dengan pendekatan partisipatif. Pada setiap pertemuan petani terlibat langsung dalam kegiatan sekolah lapang. Kegiatan diawali dengan kontrak belajar yang merupakan bentuk partisispasi petani dalam perencanaan pembelajaran. Pada tahap ini penyuluh menggali informasi dari petai dan memfasikitasi agar petani mau merencanakan proses belajar yang mereka inginkan. Kesepakatan diawal kegiatan sekolah lapang sangat penting untuk menjamin petani terlibat aktif dan membangun rasa memiliki dan kesadaran sebagai bagian dari program. 
Pada pertemuan-pertemuan selanjutnya petani didorong untuk aktif dalam penyuluhan melalui sekolah lapang. Inti sekolah lapang adalah mendorong petani untuk melihat dan menemukan masalah dan berupaya memecahkan maalah dengan berdiskusi sesama petani atau dengan fasilitataor. Oleh karena itu di setiap pertemuan petani tidak hanya sekedar datang dan mendengar penjelasan penyuluh, tetapi mengamati, berdiskudi dengan fasilitator sesama petani serta melakukan setiap rangkaian paket teknologi yang dianjurkan. Peran penyuluh diposisikan sebagai fasilitator yang memelancarkan proses pembelajaran.

Tingkat Pengetahuan Sikap dan Keterampilan Petani Tentang Teknologi Jarwo Super
Sesuai dengan tujuan program , SL Jarwo Super bertujuan untuk memberikan pemahaman kepada petani tentang sistem tanam jarwo super. Pemahaman petani tentang jarwo super dapat dilihat dari tingkat pengetahuan, sikap dan keterampilan mereka terkait dengan perangkat inovasi jarwo super. Identifikasi tingkat pengetahuan, skap dan keterampilan petani terkait jarwo super diuraikan pada Tabel 3. Hasil temuan menunjukkan bahwa petani memberikan respon positif terhadap kegiatan penyuluhan tentang jarwo super. Hal ini terlihat dari tabel 3 bahwa aspek pengetahuan, sikap dan keterampilan petani terkait teknologi jarwo yang ditunjukkan oleh sikap petani mencapai $88,89 \%$ pada tingkat baik.

Tabel 3. Tingkat Pengetahuan sikap dan keterampilan patani tentang jarwo super

\begin{tabular}{llcc}
\hline Aspek & Interval & Jumlah(orang) & Persentase \\
\hline Pengetahuan & rendah $(1-2,67)$ & 0 & 0 \\
& sedang $(2,68-5,34)$ & 18 & 100 \\
& Tinggi $(5,34-8)$ & 0 & 0 \\
\hline Sikap & rendah (12-24) & 0 & 0 \\
& sedang (25-36) & 2 & 11,1 \\
& Tinggi (36-48) & 16 & 88,8 \\
\hline Keterampilan & rendah (7-14) & 1 & 5,5 \\
& sedang (15-21) & 9 & 50 \\
& Tinggi (22-28) & 8 & 44,4 \\
\hline
\end{tabular}

Artinya adalah petani telah memahami bahwa teknologi jarwo super adalah teknologi yang tepat guna dan bermanfaat bagi usahatani padi sawah 
yang mereka lakukan. Temuan ini sejalan dengan penelitian Asaad (2017) yang menyatakan bahwa sebagian besar petani memberikan respon positif terhadap teknologi jajar legowo. Senada dengan temuan Luran dan Lampe (2016) yang menyatakan bahwa Sekolah lapang mendorong proses aplikasi pengetahuan dari luar dan lokal.

Analisis yang dilakukan terhadap pengetahuan petani menunjukan bahwa teradapat beberapa komponen pengetahuan yang belum dipahami oleh petani yakni terkait dengan jarak tanam dan pengolahan tanah sebelum proses tanam. Semua petani menjawab salah untuk kedua pertanyaan tersebut. Pengetahuan petani terkait dengan pengertian sistem jarwo super, keuntungan, manfaat termasuk pada kategori sangat baik.

Sikap petani terhadap SL jarwo super menunjukkan hasil yang baik, hal ini terlihat dari sikap petani terhadap teknologi jarwo super terkategori sedang dan tinggi. Komponen pertanyaan dalam mengukur sikap petani menyangkut aspek kemudahan teknologi diikuti, kemudahan dipelajari dalam kegiatan SL, kemudahan dalam penerapan dan ketersediaan informasi dan sarana produksi.

Terkait dengan keterampilan tentang jarwo super, temuan dilapangan adalah bahwa rangakaian teknologi yang sulit mereka aplikasikan adalah pemakaian alat dan mesin pertanian. Pemakaian alsintan seperti mesin penanam (tranplanter) dan mesin panen (combineharvest) adalah salah satu rangkaian teknologi jarwo super. Petani telah diberi bantuan perkelompok terkait kedua alat ini. Akan tetapi petani mengalami kesulitasn dalam mengapliaksikan kedua mesin tersbeut. Kondisi petakan sawah yang relatif kecil meruapakan alasan yang diampaikan petani. Petakan sawah yang kecil menyebabkan penggunaan alat dan mesin ini merepotkan petani karena petani harus memindahkan mesin ke setiap petakan.

\section{Perubahan Setelah Program}

Pembelajaran atau penyuluhan dengan metode sekolah lapang ini diharapkan membawa perubahan pada cara bertani padi sawah petani dan pada akhirya perubahan tersebut dapat meningkatkan produksi padi. Hasil penelitian menunjukan peningkatan pengetahuan terjadi sebanyak 71 point setara dengan $47 \%$, sedangkan peningkatan keterampilan adalah 43 poin atau $17 \%$. Kondisi ini menerangkan bahwa sekolah lapang jarwo super telah menambah pengetahuan dan keterampilan petani tentang inovasi baru menanam padi. Perubahan ini seyogyanaya berkontribusi terhadap 
adopsi petani terkait jarwo super dan mempengaruhi peningkatan produksi padi

Sebagaimana telah diungkapkan sebelumnya bahwa tujuan SL jarwo Super ini selain meningkatkan kemampuan petani dalam berusahatani padi menggunakan inovasi Jarwo Super adalah meningkatkan produksi. Peningkatan peroduksi merupakan tujuan dari kegaiatan SL yang diharapkan dapat meningkatan pendapatan petani padi.

Peningkatan produksi dihitung dengan membandingkan produksi per haktar tanaman padi sebelum penerapan SL jarwo Super dengan produksi tanman padi setelah menggunakan Jarwo Super. Hasil evaluasi menunjukan bahwa sebelum penerapan Jarwo Super rataan produksi padi petani adalah 5,5 ton/ha sedangkan setelah penerapan Jarwo super produksi mencapai 8 ton/ ha.

Hasil evaluasi menunjukan bahwa belum semua petani menerapkan sistem jarwo super. Informasi yang diperoleh dari ketua kelompok menerangkan bahwa sekitar $30 \%$ petani yang tergabung dalam KWT Delima adalah buruh tani. Posisi sebagai buruh tani menyebabkan mereka tidak leluasa untuk menerapkan teknologi atau cara bertanam yang baru. Mereka khawatir produksi akan menurun saat menggunakan teknologi baru, dan akan mneimbulkan masalah dengan pemilik lahan. Menurut Indraningsih (2011) keputusan petani dalam menerapkan teknologi menurut merupakan proses mental sejak pertama kali mengetahui suatu inovasi, membentuk sikap terhadap inovasi tersebut, mengambil keputusan untuk mengadopsiatau menolak,mengimplementasikan ide baru, dan membuat konfirmasi atas keputusan tersebut. Proses ini terdiri atas rangkaian pilihan dan tindakan individu dariwaktu ke waktu atau suatu sistem evaluasi ide baru dan memutuskan mempraktekkan inovasi atau menolaknya.

\section{Pencapaian Tujuan Evaluasi Metode Tyler}

Evaluasi program dengan metode Tyler pada prinsipnya mengevaluasi apakah program yang dijalankan telah sesuai dengan tujuan. Dapat dikatakan evaluasi Tyler ini berorientasi tujuam. Evaluasi yang dilakukan terhadap program sekolah lapang jajar legowo superdi KWT Delima Desa Situ Gede menunjukan bahwa tujuan progran telah tercapai dengan tingkatan yang bervariasi. Tujuan program ini adalah memberikan pengetahuan dan teknologi baru kepada petani padi sawah terkait jajar legowo super dan tujuan selanjutnya adalah meningkatkan produksi padi. 
Hasil evaluasi menunjukan bahwa penyebaran informasi melalui SLI telah memberikan pengetahuan, sikap dan keterampilan baru bagi petani. Hal ini terlihat dari tingkat pengetahuan, sikap dan keterampilan petani yang berada pada kondisi sedang dan tinggi. Perbandingan pengetahuan dan keterampilan petani sebelum dan sesudah program menunjuan adanya peningkatan. Berkaitan dengan tujuan kedua, penerapan SL Jarwo Super telah menyebabkan peningkatan pendapatan produksi.Perubahan ke arah lebih baik yang terjadi pada program ini tidak lepas dari proses pelaksanaan yang berjalan dengan baik.

\section{KESIMPULAN DAN SARAN}

Penerapan teknologi ini di tingkat petani berada pada kondisi yang bervariasi. Petani yang tergolong buruh tani mengalami kendala dalam penerapan teknologi baru karena kurangnya keleluasaan mereka mengambil keputusan terhadap usahatani yang dilakukan. Teknologi yang relatif sulit dilakukan petani adalah penerapan alsintan. Kondisi ini disebabkan lahan sawah yang tersebar dalam petakan kecil.

Evalausi program Sekolah Lapang Jajar Legowo Super menunjukan hasil bahwa program telah berjalan dengan baik dan mampu mencapai tujuan program. Tercapainya kondisi tersebut tidak lepas dari pengelolaan proses kegiatan yang berlangsung dengan baik dan dukungan berbagai pihak. Penyebaran teknologi baru perlu terus dilakukan kepada petani dengan pendekatan-pendekatan yang bersifat partisipatif. Temuan pada evaluasi ini menindikasikan perluny apemetaan petani atas status meraka pakah sebagai buruh tani, pemilik atau penggarap. Kejelasan status ini akan memudahkan perumusan kegiatan program penyuluhan kedepan.

\section{DAFTAR PUSTAKA}

Arikunto, S dan Jabar SA. 2009. Evaluasi Program Pendidikan. Jakarta. Bumi Aksara.

Asaad M, Bananiek S, Warda, Abidin Z. 2017. Analisis Persepsi Petani Terhadap Penerapan Tanam Jajar Legowo Padi Sawah Di Sulawesi Tenggara.

JurnalPengkajiandanPengembang anTeknologiPertanian, Vol. 20, No.3,November2017: 197-208

Balitbangtan. 2013. Sistem Tanam Legowo. Badan Penelitian dan Pengembangan Pertanian Kementerian Pertanian.

Balitbangtan. 2016. Rekomendasi Pemupukan N, P, dan K pada Padi Sawah Spesifik Lokasi. Badan Penelitian dan Pengembangan Pertanian. 
Bhaktiar, Syarifudin (2011) Peran

Penyuluhan Pertanian Lapangan (PPL) Dalam Program Sekolah Lapang Pengelolaan Tanaman Terpadu (SLPTT) Komoditas Padi (Oryza sativa) (Studi Kasus Kelompok Tani Rukun Makmur di Desa Selopanggung. Sarjana thesis, Universitas Brawijaya. Tesis. Universitas Brawijaya.

Direktorat Jenderal Tanaman Pangan. 2016. Petunjuk Teknis Teknologi Tanam Jajar Legowo. Jakarta. Dirjentanpan.

Ikhwani, Pertiwi GR, Paturohman E, Makasim AK.. 2013. Peningkatan Produktivitas Padi Melalui Penerapan Jarak Tanam Jajar Legowo. Jurnal Iptek Tanaman Pangan Vol. 8 No. 2201372 Indraningsih KS, Pengaruh Penyuluhan Terhadap Keputusan Petani Dalam Adopsi Inovasi Teknologi Usahatani Terpadu Jurnal Agro Ekonomi, Volume 29 No.1, Mei $2011: 1-24$

Lin, XQ, D.F. Zhu, H.Z. Chen, and Y.P. Zhang. 2009. Effects of plant density and nitrogen application rate on grain yield and nitrogen uptake of super hybrid rice. Rice Science 16(2):138-142

Luran NF, Lampe M. Membangun Komitmen, Disiplin dan Kretivitas Petani Melalui 'Sekolah Lapang Petani' SLP-PHT. Jurnal Etnosia. Vol. 01, No. 01, Juni 2016.

Mardikanto (2007) Sistem Penyuluhan Pertanian. Surakarta: UNS Press.

Putra, ATA. 2012. Evaluasi Program Pendidikan 'Pendekatan Evaluasi Program Berorientasi Tujuan (Goal-Oriented Evaluation Approach: Ralph W. Tyler).

Rogers EM, Shoemaker FM. 1981. Memasyarakatkan Ide-ide Baru. Terjemahan Hanafi. Surabaya (ID). Penerbit Nasional 